\title{
"Freely you have received, freely give": A Socio-Ethical Analysis of Charismatic Engagements and Pentecostalism in Nigeria
}

\author{
Sunday Daniel AJAYI \\ Christ Apostolic Church Theological Seminary, Ile Ife, \\ Ibadan Campus, Nigeria \\ Email: ajayisdaniel@gmail.com \\ Olumuyiwa Olusesan FAMILUSI Ph.D \\ Department of Religious Studies, \\ University of Ibadan, Ibadan, Nigeria \\ E-mail: fameofame@yahoo.com \\ Doi: https://doi.org/10.46222/pharosjot.1036
}

\begin{abstract}
The manifestation and demonstration of spiritual gifts have always generated a lot of argument among Christians and non-Christians in Nigerian society. While some people deny the reality of the gifts thereby camping with the cessationists, other parties submit to the continuation of the spiritual gifts among the contemporary Christians. However, in scholarship the discourse has taken different dimensions which include the theological, effectual, biblical and philosophical perspectives with little attention paid to the socio-ethical aspect of the matter which is the major concern of this paper. The work is premised on Thomas Hobbes' Theory of Psychological Egoism, which emphasises the benefit or reward as the motivating factor for every action performed by man, this article intends to investigate the alleged commercialization of prophetic gifts among the Nigerian pastors and to determine whether this is the major cause for the increase of the demonstration of charismatic gifts in the country. Interviews were conducted with Christians and ministers for data collection; which were complemented with relevant literature. The paper pays attention to charismatic display and Pentecostalism, current level of charismata in Nigerian Pentecostal churches, encouraging factors of charismatic activities and socio-ethical assessment of the display of spiritual gifts in Nigeria's churches, while Christian morally pertinent ways of demonstrating spiritual gifts in an ethical manner is recommended
\end{abstract}

Keywords: Charismatic engagement, Ethics, Spiritual gifts, Pentecostalism

\section{Introduction}

There are many dimensions of discourse of the reality, continuation and exercise of the spiritual gifts among Christians and non-Christian in Nigeria. The discourse has assumed a polemical dimension with some people holding to the belief of continuity of the spiritual gifts demonstrated by Jesus and His disciples in the contemporary Christian community. The Pentecostal churches are well known for this stand, for they do not only believe in the reality of the gifts but also demonstrate such either in the congregational programmes or at personal level. It is obvious that some people do not believe in the reality of the spiritual gifts holding to its cessation immediately after the generation of the apostles of Christ in the Bible ${ }^{1}$. However, without necessarily going into the debate of its continuity or discontinuity either via exegetical

\footnotetext{
${ }^{1}$ Joseph K. Koech, "Controversial Charismatic Gifts and the Church in Kenya Today" in Global Journal of Humanities and Social Sciences, Vol. 3, No 10 (October, 2015), 26
} 
or expository proofs, the camp of those who believe in the manifestation of the charismatic ability by the prophets and other ministers of God in this generation has always been advantaged in this respect. This has been established based on the experiential theology of individuals, especially in Nigeria.

The concern of this piece is not centred on the reality of the charismata, but having studied the activities of the Pentecostal Christians in the society, especially the demonstration of the charismatic gifts and ability, it is imperative to pay attention to the ethical evaluation and assessment of the usage of the spiritual gifts in relation to the social norms and the scriptural commandment as regard the subject matter. One of the major sources of Christian ethics is the Bible, and from it criticisms and appraisals are always forwarded concerning human actions displayed by Christians in the society. According to Nicolaides, the New Testament, is the primary book of Christian revelation and the most fundamental basis from which the inspiration of the Holy Spirit is obtained ${ }^{2}$. Therefore, the continuous outcry on the immoral displays of some Pentecostal ministers in the name of exercising spiritual gifts is worthy of scholarly attention. This is because the exercise of these gifts has been interpreted by some as a means of exploiting the gullible in the society, and a way of arrogating cheap fame to oneself. Nicolaides argues that also from an Orthodox perspective:

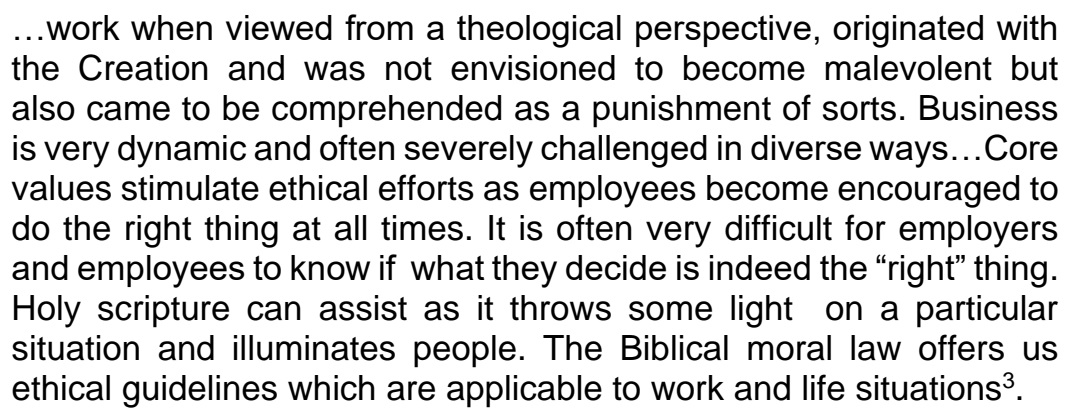

The same author avers in another publication that the Christian worldview and the role of spirituality as an alternate approach to probing ethical matters is essential. The Orthodox Christian Holy Bible speaks commandingly and expansively on all aspects of life, including desired conduct in business activities and thus also in pastoral affairs ${ }^{4}$. The foregoing affirms the impeccability of the Bible as the main source of Christian Ethics.

Using Thomas Hobbes' psychological egoism as the theoretical framework, the paper investigates the factors that led to the increase of the claims of manifestation of charismatic gifts in Nigeria through the employment of interview as a research method, and also investigate how personal gains drive the trend of charismatic ministry in the society. Attention is paid to charismatic display and Pentecostalism, the current level of charismata in Pentecostal churches, encouraging factors of charismatic ministry, and socio-ethical assessment of charismatic displays in Nigerian churches, while effort is made towards recommending Christian ethical ways of demonstrating spiritual gifts before the concluding remarks.

\footnotetext{
${ }^{2}$ Nicolaides, A. (2010). 'The Laos tou Theou - an orthodox view of the "people of God"', HTS Teologiese Studies / Theological Studies, 66(1).

${ }^{3}$ Nicolaides, A. (2020a). Ethics and the dignity of work: An Orthodox Christian perspective, Pharos Journal of Theology, Vol. 101.

${ }^{4}$ Nicolaides, A. (2020b).Contemplating Christian ethics and spirituality for sound leadership in organisations, Pharos Journal of Theology, 101.
} 


\section{Theoretical Framework}

The paper adopts Thomas Hobbes' psychological egoism as the theoretical framework. The theory poses that man is psychologically wired to do what will favour him and avoid what will not bring him any good. It claims that man is by nature selfish and self-seeking, that every man is always seeking his interest in whatever he does. In other words, Hobbes opines that whenever a person does anything, he does it only because he has seen that somehow, either directly or indirectly, either immediately or in the future, he will derive some benefits from it. ${ }^{5}$ Indeed, Thomas Hobbes holds that, to act, to promote one's interest alone is an essential nature of man, submitting that nobody would do anything if he sees that he will derive no benefit from it. Obviously, the theory claims that behind any human action there is always a selfish motive and often malevolent aspect which prompts it and which act as the driving force. Man, according to Hobbes, has certain natural appetites and aversions: he is naturally moved towards the satisfaction of his appetites and away from the objects of his aversion.

Egoism as a theory holds that the target of individuals in displaying one action or the other varies and that the intention will serve as impetus that will help to display this target inform of action, while the intention may be hiding from the people around, the doer of the action is well informed psychologically about the whole process. This can take various forms; it can take the form of a desire for fame, desire for wealth, a desire for praise, a desire for power, a desire for money or honour. This implies that man always wants something for himself, otherwise he would do nothing, and in the course of pursuing the satisfaction of their appetites men always clashed with each other, quarrelled with each other and fought with each other. Harrison summarises the theory when he asserts that egoism implies that "each person ought to do whatever maximizes his or her own self-interest regardless how this affects others"6

A series of argument have been raised against this theory, many of which argue in favour of altruism $^{7}$. For example, there are many instances when we help other people without even thinking of any personal gain or benefit accruing from such actions, on this ground, some scholars submit that psychological egoism is faulty and that it is wrong to think of man as a self-seeking being ${ }^{8}$. In defence of this theory, Hobbes opined that there is a sense of emotional satisfaction and psychological importance or relevance that follow helping people who could not reciprocate the help, and the expectation of divine reciprocation in form of blessing, for those who believe in God, could make them exhibit some actions which would look altruistic facially but egoistic psychologically. To him, people are quite intelligent and they always find a way to mask what is their interest and present them as acts of altruism. However, one is tempted to believe Omoregbe when he asserts that:

Man has, by nature, the potentialities for both selfishness and altruism because he is by nature both individual and social. Whether a person becomes selfish or altruistic depends on which of these potentialities he develops. ${ }^{9}$

\footnotetext{
${ }^{5}$ Joseph Omoregbe, Ethics: A Systematic and Historical Study (Lagos: JERPL, 1993), 79

${ }^{6}$ Mike Harrison, An Introduction to Business and Management Ethics (New York: Palgrave Macmillan, 2005), 45

${ }^{7}$ Yung-An Hu and Day-Yang Liu "Altruism Versus Egoism in Human Behavior of Mixed Motives" in American Journal of Economic and Sociology, Vol. 62, Issue 4 (September, 2003) 34

${ }^{8}$ S. Rachels, "Nagelian Arguments Against Egoism" in Australasian Journal of Philosophy, Vol. 80 (08 April, 2010), 191-208.

${ }^{9}$ Joseph Omoregbe, Ethics: A Systematic and Historical Study, 80
} 
The statement above suggests that if a person develops the potentiality for altruism he will become altruistic; on the other hand if he develops the potentiality for selfishness, he will become selfish. This singular fact could make human action ethically evaluative, for man has ability and choice to either be morally upright or morally bankrupt. For if man is naturally wired to exhibit only the actions that would favour him alone, even when these actions are morally wrong, it would be unethical to blame man for actions exhibited because he would not have behaved otherwise, but because of the ability to choose either good or evil, he will take full responsibility of his actions.

The theory is relevant to the subject under discussion because many pastors of Pentecostal churches are claiming that God ordained them into the ministry because of the good of the people in their churches, while allegation of commercializing the spiritual gifts is proving the point that many of these ministers are into the ministry, and are using the gifts for their own benefits, whereas, they have the ability to use it altruistically. One of the popular biblical verses used in criticising pastors that are administering spiritual gifts to people for their personal gain is Matthew 10:8, where Jesus commanded His disciples to freely use the gifts for delivering of people who were oppressed, simply because they freely received the gifts from God. Therefore, it is an aberration against Christian Ethics to submit to egoism in the usage of charismatic ability in churches. Thus, the data gathered are analysed using ethical tools to determine if the some Pentecostal ministers actually submitted to this theory and abandoned altruism as popularly alleged.

\section{Pentecostalism in Nigeria}

The churches that are referred to as Pentecostals are the ones that believe in the physical manifestation of the Pentecostal experiences in contemporary Christian community. In Nigerian context, the Pentecostal churches emphasize, among other things, the Holy Spirit, spiritual gifts, miracles, healings, signs and wonders and power encounters. It is believed that the first move of Pentecostalism in Nigeria came with the emergence of Aladura movement, which laid emphasis on the baptism of Holy Spirit, in the country. This began around 1910, but became obvious, irresistible and famous beginning from the 1930s. It is right to agree with Ojo who asserts that the greatest growth in Christianity in Western Nigeria took place between the 1930s and the1940s, when the prophetic and healing ministries of the Aladura attracted several people of the area to the Christian faith. ${ }^{10}$

Several nomenclatures have been adopted by scholars to differentiate the Pentecostal churches from the mainline ones; these include "Neo-Pentecostal" churches (NPCs), "charismatic" churches or ministries (CMs), born again churches among others ${ }^{11}$. These names came to being as a result of the prevailing characteristics of the movements, especially, their emphasis on spiritual gifts, holiness and regeneration of soul. One of the beliefs of the Pentecostals is the ability to perform both deliverance and exorcism, while the former has got to do with the general idea of freeing people from the bondage of Satan; the latter is a specific act of binding and releasing, performed on a person who is believed to be possessed by a non-human malevolent spirit. ${ }^{12}$ The claim of these churches is scripturally proven, holding to the statement of Jesus Christ to his disciples that he has empowered them to cast out the demons and to set free the oppressed.

10 Matthew Ojo, "Of Saints and Sinners: Pentecostalism and the Paradox of Social Transformation in Modern Nigeria": An Inaugural Lecture Delivered at the Obafemi Awolowo University, Ile Ife on $18^{\text {th }}$ June (Ile Ife: OAU Press Limited), 7

${ }^{11}$ Anderson Allan, An Introduction to Pentecostalism (Cambridge: University Press, 2004), 1

12 Abamfo Atiemo, "Deliverance in Charismatic Churches in Ghana"., Trinity Journal of Church and Theology Vol. Iv (3) (Dec/Jan, 1994/5), 40 
There are various kinds of Pentecostal churches in Nigeria, the difference among them is doctrinal, periodical and pedagogical, and this has resulted into different classifications of these movements among the scholars. Some of these will be examined in order to identify the factors that led to the categorisation. Ajani ${ }^{13}$ gives periodic or dispensational classification of the Pentecostals when he notes that the first phase of Pentecostalism in Nigeria was the early 1900 s and 1960 which was associated with the Aladura movement, while the second phase was between 1970s and 1980s which was a period of the rise of trans-denominational Pentecostal movements. The third phase is dated from the 1990s to date which one could refer to as coping movements, this is because they preach coping strategies to Nigerians in the midst of economic hardship. This is done either by consoling the poor to live holy life in order to enjoy in heaven or to pray for the deliverance of the poor from the 'demon' that caused the poverty.

According to Ayegboyin ${ }^{14}$, Pentecostals in Nigeria are functionally grouped under three main categories namely, the Holiness Movements, which stress holiness and righteousness in their doctrinal teachings, The Deeper Life Bible Church is a good example of this group. The second group is the Prosperity Organizations that emphasise material and physical success and breakthrough in their hermeneutical exposition of the scriptures. Example of this is Living Faith Church, Worldwide (Winners' Chapel), to them, success and breakthrough are synonymous to prosperity. ${ }^{15}$ Folarin asserts that churches under this category usually frame attracting themes of programmes that promise prosperity for the attendants. ${ }^{16}$ The third is the Deliverance Ministries where Mountain of Fire and Miracle Ministries is an obvious example. In these ministries, it is believed that 'spiritual' weapons are used to set free those who are possessed by the demons.

In Ojo's opinion, Pentecostals in Nigeria should be classified based on their dispositional outlooks. He lists six categories, which are, the faith seekers, who are ascetic conversionists, the faith builders, who emphasize the potentials of individual to overcome life's challenges; the faith transformers, who seek the conversion of isolated ethnic groups; the reformists who remain within the mainline churches; the deliverance churches which lay emphasis on the need of freedom from demonic activities and the modernists who seek to present the faith to the people in modern forms. ${ }^{17}$

\section{Nigerian Pentecostal Churches and Charisma}

One of the major distinguishing qualities of Pentecostal churches is the claim of the manifestation of the spiritual gifts. It is strongly believed among the Pentecostals that the power of God is able to solve all human problems. This belief was at its extreme even when the Aladura churches emerged in Nigeria during which medical treatment was forbidden for the members of the group because of the strong belief in divine healing. It therefore became

${ }^{13}$ Ezekiel O.A. Ajani, "Pentecostal Movements and the Reshaping of Christianity in Africa" Orita Ibadan Journal of Religious Studies, XLV (June \& December, 2013), 253

${ }^{14}$ Deji Ayegboyin, ““...But deliver us from Evil...' The Riposte of the MFM and its Implication for the 'Reverse in Mission"” Orita: Ibadan Journal of Religious Studies, Vol. XXXVII (June \& December, 2005), 36

15 S.O. Ademiluka, Issues at Stake in the Contemporary Nigerian Church (Ilorin: Nathadex Publishers, 2007), 116

${ }^{16}$ George O. Folarin, "A Critique of Responses of Selected Pentecostal Churches to the Problem of Poverty in Nigeria" Orita: Ibadan Journal of Religious Studies, Vol. XLIII/1 (2011), 61

${ }^{17}$ Matthew Ojo, "Of Saints and Sinners: Pentecostalism and the Paradox of Social Transformation in Modern Nigeria" 25-31 
'sinful' for any member to take drugs or to receive medical treatments. It was gathered in 1930s that some Christ Apostolic Church members that defaulted the tradition of divine healing and went to hospital for medical care who eventually died in the hospital were not given burial rite by the church. The minister in charge of such assembly could be excommunicated if he ministered at the burial ceremony of the deceased. ${ }^{18}$ Dada further stresses the operation of the Pentecostals in Nigeria:

\begin{abstract}
Among the Yoruba of Southwest Nigeria where most of the indigenous Pentecostal Churches are concentrated in Nigeria, they are called ijo emi (Church where activities of the Holy Spirit are emphasized). The interest of these churches in faith healing and exorcism has earned them the name prophetic and healing ministries. ${ }^{19}$
\end{abstract}

One unique and obvious fact is that Pentecostal churches and the manifestation of the spiritual gifts have always been providing 'solutions' at difficult periods in the Nigerian history. For instance, the prophetic-healing activities of the Pentecostal Aladura group played a vital role in stilling the whirlwind of the epidemic in some parts of the world during the closing years of the World War I. ${ }^{20}$ Also, the Neo-Pentecostal churches have been providing a strong 'solace' for Nigerians to cope with the financial hardship inflicted by political corruption and bad leadership through prosperity preaching, deliverance from 'demon' of poverty and emphasis on holiness that can grant transition to heaven where no poverty could reach. ${ }^{21}$

Apart from the healing activities, the Pentecostal churches believe that there is nothing that cannot be prayed about. They hold to the saying that "what worth worrying about is worth praying about'. This fact coupled with the orientation of an African man who is not only notoriously ${ }^{22}$ and incurably ${ }^{23}$ but also in all things ${ }^{24}$ religious, the Pentecostal churches have technically replaced the Ifa shrine where oracles were consulted before laying hands on any endeavour. Therefore, many Pentecostal leaders in Nigeria continued to exhibit charismatic

\footnotetext{
${ }^{18}$ Personal Interview with Pastor Samuel A. Adelabu on 18 February, 2018. He is about 80 years old. He is the Church Planter of Christ Apostolic Church, Oke Iyanu, Majorogbe, Ajibode, Ibadan, Oyo State. He specifically gave instances of how pastors ignored members who died in hospital when he joined Christ Apostolic church at Igbo Ora Oyo State around 1940s.

${ }^{19}$ Adekunle O. Dada, "Music and Prophetic Inspiration in Selected Indigenous Pentecostal Churches in Nigeria" Orita: Ibadan Journal of Religious Studies, Vol. XLII/2 (December, 2010), 152

20 S.A. Fatokun, "The Apostolic Church Nigeria: The 'Metamorphosis' of an African Indigenous Prophetic-Healing Movement into a Classical Pentecostal Denomination" Orita: Ibadan Journal of Religious Studies, Vol. XXXVIII, (June \& December, 2006), 51

21 Philomena Njeri Mwaura, "A Spirituality of Resistance and Hope: African Instituted Churches' Response to Poverty" Orita: Ibadan Journal of Religious Studies, Vol. XXXVII, (June \& December, 2005), 74

22 J.S. Mbiti, African religions and philosophy, (Oxford: Heinemann Educational Publishers, 1989), 1

${ }^{23}$ E.G. Parrinder. Religion in Africa, (Harmondsworth: Penguin, 1969), 28-29

${ }^{24}$ E.B. Idowu, Olodumare: God in Yoruba belief, (London: Longmans Group Ltd, 1962), 146
} 
gifts of courage, oratory prowess, counseling, auction, miracles, signs and wonders which make them to pull crowd. ${ }^{25}$

The recent development in the Pentecostal circle is that a particular ministry is built on the charismatic leader, where people view such leader as the divine link to their desired blessings. The size of the followers of the Pentecostal leaders is largely determined by their display of charismata. Thus, patronization of churches is based on the ability of their leaders to exhibit spiritual gifts of healing, exorcism, words of knowledge, prophetic utterances, speaking in tongues among others, if not, the denomination could experience mass exodus of members to another denominations where their leaders are charismatically sound. It is not strange to witness churches holding series of programmes either to attract new members or to retain the old ones. This is because the Pentecostals churches are competing with one another in order to gain more people to their churches. It is obvious, that people are no longer joining churches only because of worship, but to also associate with the call and charisma of the leader, believing that his 'anointing' will surely pave way for them in all facets of life. Attention will be paid to the changes that have happened to Pentecostalism in Nigeria which have shifted it from its original position.

\section{New 'Innovations' in Nigerian Pentecostal Churches}

The philosophy and goal of the Pentecostal churches in Nigeria have been shifted from what obtained at its inception. Many factors are responsible for this odd change, which will be enunciated later. The current stage of the display of charismatic gifts is no longer solely for the salvation of souls, neither for the equipping of the saints nor for the edifying of the body of Christ (Ephesians 4:11-12). Although there is an increase in the number of Pentecostal groups in Nigeria, there is also a correspondent increase in the display of immoral, unethical and unbiblical exhibitions in the midst of some of the leaders of these groups and their followers. The cause of this abnormal correspondent increase can be best described in the words of Ayegboyin when he asserts that:

The social setting of the 1980s gave birth to a plethora of Pentecostal groups, ministries, churches and para-churches, all of these competing for membership. The proliferation came to a peak in the 1990s, which was marked by increased economic hardship, political crisis, social upheavals, moral chaos and value confusion. ${ }^{26}$

It has been discovered that because of the economic hardship and other factors mentioned in the above quotation, the use of the spiritual gifts among the Pentecostals has been seriously affected. This implies that in response to this hardship, some of the biblical and ethical values that were attached to the Pentecostalism from its inception have been abused. The Pentecostal churches are known for fervent and violent prayers from the beginning, but the innovation that came to this quality is what is referred to as 'prayer contractor', where some groups or an individual will be paid certain amount of money to help pray on a particular situation. ${ }^{27}$ This is nothing but the monetization of the spiritual gifts which could be referred to

${ }^{25}$ Maria N. Ajayi, Gerisho Kirika \& Johnson Mavole. "Traditional Healing Practices and Holistic Health: The Implication for Christian Families in South West Region of Nigeria" in Journal of Family Medicine and Health Care. Vol. 5, No. 4, (2019), 53-54.

${ }^{26}$ Isaac Deji Ayegbonyin, "Taxonomy and Revolution in African Christianity: The Nigerian Experience". An Inaugural Lecture Delivered at the University of Ibadan, Ibadan, Nigeria on Thursday (09 November, 2017), 25

${ }^{27}$ Personal Interview with Evangelist Makanjuola Simon, $6^{\text {th }}$ March, 2018 . He is about 45 years old, a student of a seminary. He revealed that there is a group at Akintola Bolverd Street Gariki 2, Abuja that is known as prayer contractor that collect money from people to help them pray 
as new 'innovation' in Pentecostalism because it is different from the experience of Apostle Peter who chose not to market the gift of God in Samaria (Acts 8:14-22).

Another new development in some Nigerian Pentecostal churches and ministries is compulsory registration and collection of tally before one could have access to the prophet or spiritual leader. The registration will be done by the personal assistant to the man of God, while the 'client' will need to pay certain amount of money for the registration. There is a popular ministry at llorin in Kwara State, where people are allegedly registering before they are allowed to explain their plights to the leader. This is a new idea because such is not recorded in the ministry of Jesus Christ neither do we read such about his disciples. ${ }^{28}$

Deliverance and healing through divine power are hallmarks of Pentecostal movements, the biblical basis for this is strongly established in the empowerment of the disciples by Jesus Christ that they have been given power to heal the sick and set free the oppressed, however, he quickly added that they received the power freely, and freely they should give the deliverance and healing (Matthew 10:1-8). It is obvious that many deliverance ministers no longer follow the instruction given by Jesus Christ as many people testified to the fact that they are charged certain amount of money before deliverance/exorcism or healing is conducted in some Pentecostal churches. ${ }^{29}$

The selling of spiritual elements that could only be likened to the practice of some church leaders who were alleged of indulgences and sales of relics in the early church before the reformation of A.D. 1517, championed by Martin Luther, is another development in contemporary Pentecostalism. ${ }^{30}$ Some pastors are specialists that deal in anointed materials like water, oil, handkerchiefs. They hold to prophetic hermeneutics of the scriptures. Their activities are captured in the description below:

\begin{abstract}
In recent times, a new strand of Pentecostal movement which may be described as "neo-prophetism", has emerged in several West African countries. In this movement, there is a profuse use of the "anointing oil" and "anointing water". ${ }^{31}$
\end{abstract}

Apart from the obvious mixture of African Traditional Religion beliefs and practices with the charismatic Pentecostal practices, the selling of these "consecrated " materials is a strategy put in place to technically exploit the gullible who are seeking miracle at all cost. For example, selling of "anointing water" is no longer a clandestine enterprise at Prophet T.B Joshua's The Synagogue Church of All Nations, as the transaction is proudly telecast on his famous Emmanuel TV. Those who do not transact publicly, however, sell these elements in their

on their problems. The members of this group are allegedly believed to have prayed for political breakthrough of Senator Ayim Pious Ayim, during the 1999 election, who later became the president of the then Senate house.

${ }^{28}$ Interview Respondent who prefers anonymity went to a church Kings Palace Assembly at Ilorin, Kwara State, and registered with certain amount of money and received tally before he could be allowed to meet with the founder of the church.

${ }^{29}$ Interview Respondent who prefers anonymity confirms that Apostle (Dr) Johnson Olayinka Afolabi popularly known as Okoto Jesu of Joyous Miracle Gospel Church and Ministry, Ogbomoso, Oyo State would not conduct exorcism or healing if the victim is not ready to pay the financial cost of the healing. There are different price tags for various illness and problem, whosoever wants to be delivered need to comply with the prerequisites.

${ }^{30}$ Stephen O. Ajayi, The History of the Christian Church (Ibadan: Kogiah Communications, 2015), 65

${ }^{31}$ Isaac Deji Ayegbonyin, "Taxonomy and Revolution in African Christianity: The Nigerian Experience", 26 
programmes. ${ }^{32}$ How can we scripturally account for the display of spiritual elements on the altars and many people are responding to the advertisement made by the pastor to make their purchase? It is nothing but a negative innovation in Pentecostalism, an immense shift from biblical standard and an aberration to Christian ethics.

The revival of sowing seed that is rampant in some Pentecostal churches today is worthy of our attention. The newest 'gospel' in many Pentecostal churches currently is how people will sow the seeds of faith in form of cash in order to experience quick miracles. ${ }^{33}$ Larger percentage of the prosperity preachers is fond of this, bank account are dictated on the altars for people to pay the money, while Point Of Sale (POS) machines are strategically located for sowing seed right there in the church. The commercialization of spiritual gifts which is proudly done under the disguise of modernization, seeks to exploit people of their resources through sugar-coated mouth and hermeneutical tools that are promising automatic and immediate multiplication of the payment made. Many people who have sown seeds that are expecting increase on the money paid in form of miracle, only to discover later that they have been cajoled by a mere motivating speaker in the church of God ${ }^{34}$.

\section{Causative Agents of Charismatic Engagements in Nigeria}

The questions that are begging for answers in the mind of concerned people in the society include: Is it the love of Christ or evangelism that is responsible for the proliferation of Pentecostal churches in Nigeria? In other words, can we say that the love of the lost souls had driven many people to charismatic ministry? Ethically, one could ask if there is altruistic notion in the use of the charismatic gifts or could the increase of charismatic movements only be explained egoistically? All these questions and many more are consciously and unconsciously agitating the minds of many Nigerians. Beyond the level of salvation of sinners, it seems as if many people are into Pentecostal ministry because of other reasons. We will consider some of the propelling factors here:

\section{Economic Hardship}

To overcome the economic problems being experienced in the country, many people have seen divine intervention as the only solution to what they feel they could get without stress in a country with a flourishing economy, stable policies and good political leadership. In Adeboye's view, one major reason for numerous prosperity organizations in form of Pentecostal movements has been the intense economic hardship occasioned by corruption which Nigerians are facing both in the military and the civilian rules. ${ }^{35}$ It is believed that this development led to the shift from the holiness doctrine to that of prosperity and faith in the Nigerian Pentecostal circle. ${ }^{36}$ The same factor was also responsible for the countless number

${ }^{32}$ Personal Interview with Evangelist Babatunde Amos, $6^{\text {th }}$ March, 2018. He is about 35 year Old. He said Rev. Father Mbaka used to sell anointing oil and anointing water in his crusade whenever he came to Abuja for ministration.

33 Celestina O. Isiramen, "Pentecostalism and the Nigerian Socio-Economic Debacle: A Therapy or a Delusion" in Celestina O. Isiramen, (Ed.) Religion and the Nigerian Nation: Some Topical Issues (Ibadan: En-Joy Press \& Books, 2010), 319.

${ }^{34}$ O.O. Familusi, "Voluntary or Subtle Compulsion: An Ethical Context of Giving as Sacrifice in Contemporary Christianity." Orita: Ibadan Journal of Religious Studies Vol. XLVIII. No. 1:.p.70

35 Olufunke Adeboye, "Transnational Pentecostal in Africa: The Redeem Christian Church of God Nigeria" in Andre Mary and Rene Otayak (Eds.), Enterprises religieuses transnationale en Afrique de l'Ouest Fourchard (Karthala: IFRA, 2005), 442

${ }^{36}$ Leke Ogunewu, "Charismatic Movements and Theological Education: Past, Present and Future" Ogbomoso Journal of Theology, Vol. XII (2) (Ibadan: Baptist Press, 2008), 63 
of Pentecostal ministers in the country, one can convincingly opine that if the economy of the nation is good and citizens are gainfully employed, many of those who claim to be ministers of the Gospel today will find their fulfilments in other professions. ${ }^{37}$ Thus, the commercialization of the charismata is highly motivated by the height of poverty many Nigerians are battling with ${ }^{38}$.

\section{Fulfilment of Personal Ego}

It has been discovered that one of the reasons behind the increasing claims of charismatic ability in Nigeria, apart from the financial gain, is the urge to be a leader by all means. According to Ajayi, many people who are supposed to be learning leadership skills under experienced ministers are establishing 'sole proprietorship businesses' but referring to them as churches, just because they want to become a leader to be 'worshipped' by their followers. ${ }^{39}$ This is obvious in the way some of the Pentecostal leaders are either commanding or demanding respect in their various churches and beyond.

\section{Religious Orientation of Nigerians}

Ordinarily, even before the coming of Christianity to the shore of African in general and Nigeria in particular, people used to patronize the traditionalists to make inquiries. With the coming of Pentecostal movement, with the healing and prophetic flavour, people quickly replaced the old religious 'giants' with the charismatic personalities. Traditionally, people pay money to inquire something from the oracle; the same orientation is brought into Christendom that payment should be made for prophetic investigation and other charismatic assistance from Pentecostal giants.

\section{Cut-throat Competition}

The Pentecostal denominations are not only competing for membership but also competing in many areas which include purchasing of land property in strategic locations, getting the largest church auditorium, having the biggest camp ground, possessing television station for advertising church programmes and establishing educational institutions at all levels, that is, from nursery school to university level. In a bid to outdo the marked 'competing' denomination, many Pentecostal leaders would search for funds in an unethical and unscriptural means, resulting in new 'innovations' in Pentecostalism. The trend among the prosperity preachers is the purchase of personal Jets. Many ministers who could not attain this level feel inferior, thus, any means must be employed in order to ride luxurious jet, since that is the new level of competition among the 'great' ministers of the gospel.

\section{Secularizing Church Leadership}

There are some benefits that are attached to the political positions in any given State; these benefits vary from state to state. Many politicians have access to official cars, personal security and bodyguards and other financial benefits. It is amazing to note that some church leaders are also living flashy life like that of the politicians. Apart from the titles upon titles ranging from bishops to apostles adopted by many Pentecostal leaders, structural and hierarchical arrangement of the leadership style adopted is not different from that of the secular, which made it difficult for common poor men who needs godly message to have access to them. We need to agree with Lawrence when he opines that it is all too easy to abandon what the

37 Sunday Daniel Ajayi, "Factoring Morality into Church Evangelism" Christ Apostolic Journal of Biblical and Theological Studies, Vol. 1 No. 1 (2016), 77

${ }^{38}$ O.O. Familusi, 2011." Corruption and the Prospect of Pastoral Ministry in the $21^{\text {st }}$ Century Nigeria". Insight: Journal of Religious Studies. Vol.7. p.104.

${ }^{39}$ Sunday Daniel Ajayi, “An Application of Jesus' Leadership Style in Contemporary Christian Ministry" The American Journal of Biblical Theology, Vol. 19(3), (January 21, 2018), 8 
Christian tradition has to offer on leadership and embrace the latest 'new thing' in secular leadership when we are too mindful of personal gain. ${ }^{40}$

\section{Socio-Ethical Assessment of Charismata in Nigerian Pentecostalism}

It is imperative to assess the use of spiritual gifts among the Pentecostal via socio-ethical lens in order to juxtapose the result with the biblical experience and ethical expectation. Going by the instruction of the empowerment in Matthew 10:1-8, it is obvious that Jesus was releasing the power to His disciples for the liberation of the people they were sent to, and that this should be done freely. However, if the Pentecostals are claiming to be obeying Christ's commandment at this regard, it should be obeyed holistically and not egoistically exercising spiritual gifts. Though the ministers of the gospel need to be catered for, Christ vehemently warned against the commercialization of spiritual gifts. It is, therefore, ethically and scripturally wrong to respond to the economic hardship through exploitation of fellow Christians. This exploitation is so glaring in some Pentecostal churches where leaders are riding different cars while their members are living in abject poverty. It is socially inimical to be extorting people that are already impoverished. Some of these pastors could only pray for those they think can pay for their services, as some of them would openly demand that you pledge what to do for them if your prayer is answered. ${ }^{41}$

Theologically, charisma is never an end in itself, but a means to an end. The hermeneutical explanation of the passages of the Bible that teach issues on spiritual gifts shows that they are given for the development of the church and perfection of the saints (Ephesians 4:11-12). Basically, spiritual gifts are not given for egoistic purposes or for commercial purposes; rather they are given to make the church stand firm and to enhance spiritual growth of the fellow Christians. The main reason for the gift is to bring people closer to God, but the opposite is the case in a situation whereby the minister is financially exploiting those he is supposed to establish in faith. The heart of people who are seeking solution to their challenges are no longer directed towards their moral inadequacies, the attention is heavily on how the gifts will solve their problems.

Since people are charged for healing and miracles, and various forms of elements are sold right on the altar of some Pentecostal churches, which is creating the impression that human beings have the power to deliver or offer salvation. The implication of this is that deliverance or salvation would be meant for only those who could afford its financial cost. This will portray God as one who could be manipulated to carry out some miracles and healing because of the financial strength of the individuals concerned, and not the God who is benevolently involved in the situation of people who call on Him. The grace of God would now be for the highest bidder, leaving the poor in the society in perpetual poverty and suffering. However, the holistic examination of the ministry of Jesus Christ, who the charismatic leaders are claiming to be their sender, shows how He took care of the poor and had relationship with people of low status.

Many charismatic Pentecostal leaders over-value themselves, simply because of the manifestation of the spiritual gifts; they raise their ego to the point of demanding for worship from their followers. Photographs of such leaders are encouraged to be displayed in shops, apartments and offices to chase away evil spirits or wrought miracles when they focus

${ }^{40}$ J. Lawrence, Growing Leaders: Reflections on Leadership, Life and Jesus (Abingdon: The Bible Reading Fellowship, 2004), 29

${ }^{41}$ Personal Interview with Evangelist Makanjuola Simon, $6^{\text {th }}$ March, 2018. He is about 45 years old, a student of a seminary. He confirmed that one Pastor Olugbenga of Holy Ghost Christian Centre established by pastor Fenwa at Mechanic Area beside Shoprite Apo, Abuja used to openly curse church members who would not pay their tithes to him after he had prayed for them for blessing. This actually occasioned his (Makanjuola) exit from the church. 
attention on it during the time of needs, while names of many of them have replaced the name of Jesus in their prayers sections, either congregational or family prayers. This supports Ayegboyin's view that:

\begin{abstract}
Regrettably, a good number of the NPC (Neo Pentecostal Church) leaders are never servants. They are strict and dictatorial. Quite a few have personalised authority and have ego problem arising from the illusion of self-importance, and of success. ${ }^{42}$
\end{abstract}

Again the over emphasis on the use of elements like "anointing oil", "anointing water" or "anointing handkerchiefs" may shift the attention of people from God to the elements, this accounts for how some people could not move out of their houses without such elements in their hands. This implies that there is an orientation that God is no longer the protector but the element given to them by their prophet. Unarguably, this idea finds it roots from African Traditional Religion, where armlets and magical rings are used as coping strategies.

\title{
Recommendations
}

Without falling into the errors of those who totally condemn all the activities of the Pentecostals, it is imperative to note that the movements have both social and religious functions in the society. However, there are many areas that need Christian ethical upgrades in the display of charismata among the Pentecostals. Care must be taken not to place money above the salvation of the souls of church members. This suggests that biblical injunctions on how to use the gifts in an altruistic manner should be completely observed.

Those who present themselves as the source of the power that performs healing, exorcism, deliverance signs and wonder should desist from this unbiblical idea as this could result to the down fall of the ministers concerned and it is also capable of leading the gullible astray. It is ridiculous to turn church altar to supermarket where buying and selling of elements is being carried out. Although studies have shown that Africans are likely to accept the gospel quickly when visible and concrete materials are used as a substance of faith, ethical method should be employed in contextualizing biblical faith.

Jesus identified with the poor and people of low status in the society, thus, the 'great' Pentecostal leaders should not build security around themselves up to the extent that they will become inaccessible for the common man. Attention should not be given to big wigs in the society alone, as they pray for politicians and people of high calibres, so also they should pray for the poor. Schools established by these denominations should have special programmes for the children of the poor in the society in order to have access to education. Through this, their ministries will take after Jesus' that catered for the need of the poor of His time.

In a bid to differentiate Pentecostal movements from the mainline churches, biblical standards and Christian ethics should not be ignored. The permission of immoral dressing in the church under the pretence of modernization in order to gain more members is not commendable, besides, employment of secular leadership skill, music and dancing steps are unwelcome in the place of worship. As a result, little effort will only be put into the gospel for effectiveness when those who are presenting it to the world become moral agents.

\section{Concluding Remarks}

The continuous unethical displays among some of the Pentecostals make people to question the genuineness of their ministries, which bring charismatic activities in these movements under a serious attack. The proliferation of Pentecostal churches in Nigeria has been

${ }^{42}$ Deji Ayegboyin, “' ‘...But deliver us from Evil...' The Riposte of the MFM and its Implication for the "Reverse in Mission"” 61 
interpreted from egoistic point of view, meaning that many of the charismatic leaders of the church are only looking for a means of exploiting their unsuspecting adherents. Therefore, to correct this notion, Christian ethical values must be given their prime place in the ministries of these movements. This will go a long way to prove that Pentecostalism has many good things to offer the society both socially and spiritually, rather than the undue commercialization of the gospel, which is characteristic of many Pentecostal churches in not only Nigerian but also global society today.

\section{References}

Adeboye, O. (2005). "Transnational Pentecostal in Africa: The Redeem Christian Church of God Nigeria" in Andre Mary and Rene Otayak (Eds.), Enterprises Religieuses.

Ademiluka, S.O. (2007). Issues at Stake in the Contemporary Nigerian Church, Ilorin: Nathadex Publishers.

Ajani, E,O,A. (2013). Pentecostal Movements and the Reshaping of Christianity in Africa, Orita Ibadan Journal of Religious Studies, XLV

Ajayi, D.S. (2016). Factoring Morality into Church Evangelism, Christ Apostolic Journal of Biblical and Theological Studies, 1(1) 77.

Ajayi, D.S. (2018). An Application of Jesus' Leadership Style in Contemporary Christian Ministry, The American Journal of Biblical Theology, 19(3).

Ajayi, M.N., Kirika, G. \& Mavole, J. (2019). Traditional Healing Practices and Holistic Health: The Implication for Christian Families in South West Region of Nigeria, Journal of Family Medicine and Health Care, 5(4), 53-54.

Ajayi, S.O. (2015). The History of the Christian Church, Ibadan: Kogiah Communications.

Allan, A, (2004). An Introduction to Pentecostalism, Cambridge: University Press UK.

Atiemo, A. (1994/5). Deliverance in Charismatic Churches in Ghana, Trinity Journal of Church and Theology, Vol. IV (3).

Ayegboyin, D. (2005). But deliver us from Evil: The Riposte of the MFM and its Implication for the 'Reverse in Mission, Orita: Ibadan Journal of Religious Studies, Vol. XXXVII.

Ayegboyin, I.D. (2017). Taxonomy and Revolution in African Christianity: The Nigerian Experience, An Inaugural Lecture, University of Ibadan, Ibadan, Nigeria.

Dada, A.O. (2010). Music and Prophetic Inspiration in Selected Indigenous Pentecostal Churches in Nigeria, Orita: Ibadan Journal of Religious Studies, Vol. XLII/2.

Familusi, O.O. (2016). Voluntary or Subtle Compulsion: An Ethical Context of Giving as Sacrifice in Contemporary Christianity, Orita: Ibadan Journal of Religious Studies, Vol. XLVIII. No. 1

Familusi, O.O. (2011). Corruption and the Prospect of Pastoral Ministry in the $21^{\text {st }}$ Century Nigeria, Insight: Journal of Religious Studies, 7. 
Fatokun, S.A. (2006). "The Apostolic Church Nigeria: The 'Metamorphosis' of an African Indigenous Prophetic-Healing Movement into a Classical Pentecostal Denomination, Orita, Ibadan Journal of Religious Studies, Vol. XXXVIII.

Folarin, G.O. (2011). A Critique of Responses of Selected Pentecostal Churches to the Problem of Poverty in Nigeria, Orita: Ibadan Journal of Religious Studies, Vol. XLIII/1

Harrison, M, (2005). An Introduction to Business and Management Ethics, New York: Palgrave Macmillan.

Hu, Y. \& Liu, D. (2003). Altruism Versus Egoism in Human Behavior of Mixed Motives, American Journal of Economic and Sociology, 62(4).

Idowu, E.B. (1962). Olodumare: God in Yoruba belief, London: Longmans Group Ltd.

Isiramen, C.O. (2010). Pentecostalism and the Nigerian Socio-Economic Debacle: A Therapy or a Delusion"? in Celestina O. Isiramen, (Ed.) Religion and the Nigerian Nation: Some Topical Issues, Ibadan: En-Joy Press \& Books.

Koech, J.K. (2015). Controversial Charismatic Gifts and the Church in Kenya Today, Global Journal of Humanities and Social Sciences, 3(10).

Lawrence, J. (2004). Growing Leaders: Reflections on Leadership, Life and Jesus, Abingdon: The Bible Reading Fellowship.

Mbiti, J.S. (1989). African religions and philosophy, Oxford: Heinemann Educational Publishers.

Mwaura, P.N. (2005). A Spirituality of Resistance and Hope: African Instituted Churches' Response to Poverty, Orita: Ibadan Journal of Religious Studies, Vol. XXXVII.

Nicolaides, A. (2020a). Ethics and the dignity of work: An Orthodox Christian perspective, Pharos Journal of Theology, Vol. 101.

Nicolaides, A. (2020b).Contemplating Christian ethics and spirituality for sound leadership in organisations, Pharos Journal of Theology, 101.

Nicolaides, A. (2010). 'The Laos tou Theou - an orthodox view of the "people of God"', HTS Teologiese Studies / Theological Studies, 66(1).

Ogunewu, L. (2008). Charismatic Movements and Theological Education: Past, Present and Future, Ogbomoso Journal of Theology, Vol. XII (2), Ibadan: Baptist Press.

Ojo, M. (2010). Of Saints and Sinners: Pentecostalism and the Paradox of Social Transformation in Modern Nigeria: An Inaugural Lecture Delivered at the Obafemi Awolowo University, lle Ife lle Ife: OAU Press Limited.

Omoregbe, J.I. (1993). Ethics: A Systematic and Historical Study, Lagos: JERP.

Parrinder, E.G. (1969). Religion in Africa, Harmondsworth: Penguin.

Rachels, S. (2010). Nagelian Arguments against Egoism, Australasian Journal of Philosophy, 80, 191-208. Transnationale en Afrique de l'Ouest Fourchard, Karthala: IFRA. 